PEMBELAJAR: Jurnal Ilmu Pendidikan, Keguruan, dan Pembelajaran

Volume 2 Nomor 2 Oktober 2018

e-ISSN: 2549-9114 dan p-ISSN: 2549-9203

(Received: Agustus-2018; Reviewed: September-2018; Published: Oktober 2018)

DOI: http://dx.doi.org/10.26858/pembelajar.v2i2.5642

\title{
Pengembangan Perangkat Evaluasi Perkembangan Bahasa Anak Usia Dini Pada Anak Tk Islam Al Markaz Al Islami Kelompok B Makassar
}

\author{
Eka Mulyaningsih \\ STKIP Muhammadiyah Palopo \\ Jalan Jendral Sudirman KM 3 Binturu Kota Palopo Propinsi Sul-Sel \\ Corresponding e-mail: ekamulyaningsih1280@gmail.com
}

\begin{abstract}
Abstrak: Penelitian ini bertujuan untuk: 1) mengetahui gambaran analisis kebutuhan pengembangan perangkat evaluasi perkembangan bahasa anak usia dini, 2) mengetahui gambaran desain pengembangan perangkat evaluasi perkembangan bahasa anak usia dini, 3) mengetahui gambaran tingkat keterlaksanaan evaluasi perkembangan bahasa anak usia dini. Penelitian ini menggunakan model Thiagarajan dan Semmel yang dikenal dengan 4-D yaitu define (pendefinisisan), design (perancangan), develop (pengembangan), dan disseminate (penyebaran). Namun pada penelitian ini hanya mencakup 3 tahapan yakni pendefinisian, perancangan, dan pengembangan. Hasil dari penelitian ini menunjukkan bahwa: 1) Perangkat evaluasi yang digunakan di TK Islam Al Markaz Al Islami Makassar untuk mengevaluasi seluruh aspek perkembangan anak dengan yang digunakan TK pada umumnya sama. Hanya saja proses evaluasi yang dilakukan tidak sesuai dengan prinsipprinsip evaluasi, bahkan evaluasi jarang dilakukan atau dilakukan tetapi tidak menggunakan metode, strategi maupun alat yang tepat. Selain itu tidak adanya perangkat evaluasi yang lebih khusus untuk mengevaluasi tiap-tiap aspek perkembangan, khususnya pada aspek perkembangan bahasa anak. Berdasarkan fenomena itu dilakukan analisis teoritik dan empirik sehingga disimpulkan bahwa dibutuhkan perangkat evaluasi perkembangan bahasa anak usia dini. 2) Hasil dari gambaran desain pengembangan perangkat evaluasi perkembangan bahasa anak usia dini disimpulkan bahwa desain ini dilakukan melalui beberapa tahap dimulai dari tahap penyusunan instrument, pemilihan format penilaian, menentukan landasan filosofi dan operasional didapatkan bahwa perlunya suatu buku pedoman untuk guru dalam pelaksanaan evaluasi dan perangkat evaluasi perkembangan bahasa anak. 3) Hasil dari gambaran tingkat keterlaksanaan metode pembelajaran melalui validasi ahli dan pengamatan observer diperoleh kesimpulan bahwa analisis pada angket respon guru (ARG) dan lembar pengamatan keaktifan anak (LPKA) terhadap pengembangan perangkat evaluasi berada pada kategori "baik" sedangkan hasil evaluasi perkembangan bahasa anak usia dini dalam lima kegiatan yaitu yang telah dikembangkan berada pada kategori terlihat $(\mathrm{T})$.
\end{abstract}

\section{Kata Kunci: Pendidikan Anak Usia Dini, Evaluasi, Perkembangan Bahasa}

\begin{abstract}
This study aims at discovering: 1) the description of analysis of evaluation tools development of children's language development, 2) the description of evaluation tools development design of children's language development, 3) the description of evaluation implementation of children's language development. This study employs Thiagarajan and Semmel model known as 4-D, namely defining, design, development, and dissemination phases. However, this study is merely covers 3 phases, namely defining, design, and development. The result of the study reveal that 1) the evauation tools used at TK Islam Al Markaz Al Islami Makassar to evaluate all aspects of children's development is almost similar used by TK in general. However, the evaluation process conducted is not in line with the evaluation principles, even evaluation is rarely conducted or is conducted but without using a method, strategy, or appropriate tools. Moreover, there is no particular evaluation
\end{abstract}


tools to evaluate each aspect of development, particularly children's language development aspect. Based on those phenomenon, theoretical and empirical analyses are conducted and concluded that the evaluation tools of children's language development is needed, 2) the result of the description of evaluation tools development design of children's language development concludes that the design is conducted through several steps starting from instrument arrangement, assessment format selection, to philosophical and operational foundation decisions which obtained that a manual book for teachers in implementing evaluation and evaluation tools of children's language development is needed, 3) the result of the description of learning method implementation through validation by the experts and observation by the observant concludes that the questionnaire analysis on teachers' response and observation sheet on children's activeness toward evaluation tools development is in good category; whereas, the evaluation result of children's language development in five activities developed is in visible category.

\section{Keywords: $\quad$ Early Childhood Education, Evaluation, Langnguage Depelop}

(C2018 -Pembelajar Universitas Negeri Makassar. Ini adalah artikel dengan akses terbuka dibawah licenci CC BY-NC-4.0 (https://creativecommons.org/licenses/by-nc/4.0/) ).

\section{PENDAHULUAN}

Kemampuan berbahasa merupakan salah satu potensi yang dimiliki anak sejak lahir yang perlu dikembangkan. Jika kemampuan berbahasa anak berkembang dengan baik, maka anak tidak saja berkembang dalam bidang akademik, tetapi anak mampu pula berinteraksi secara baik dengan lingkungan sosialnya. Kemampuan berbahasa anak akan berkembang sejalan dengan rasa ingin tahu serta sikap antusias yang tinggi. Kemampuan berbahasa anak berkembang sejalan dengan intensitas interaksi anak dengan teman sebayanya. Anak dapat mengekspresikan menggunakan bahasa, sehingga orang lain dapat menangkap apa yang dipikirkan oleh anak. Melalui bahasa, komunikasi antar anak dapat terjalin dengan baik sehingga dapat membangun hubungan. Kemampuan bahasa dianggap sebagai salah satu indikator keberhasilan seorang anak.

Proses belajar mengajar di TK disusun dalam sebuah Rencana Kegitan Harian yang mencakup seluruh aspek perkembangan pada anak termasuk aspek perkembangan bahasa. Dalam setiap kegiatan dilakukan evaluasi/penilaian untuk mengetahui perkembangan anak, termasuk pada aspek perkembangan bahasa anak. Evaluasi terutama ditujukan terhadap setiap usaha yang dilakukan oleh anak, sehingga setiap anak mendapatkan apresiasi dan dorongan untuk terus tumbuh dan berkembang.

Proses evaluasi dalam PAUD, meliputi pengamatan, pencatatan, dan pendokumentasian kinerja dan karya siswa serta bagaimana proses anak menghasilkan karya tersebut (Grace \& Shore, 1991; Kumano, 2002).

Evaluasi pada dasarnya adalah melakukan judgment terhadap hasil penilaian, maka kesalahan pada penilaian dan pengukuran harus sekecil mungkin. Pendapat lain dikemukakan oleh Bloom et. al (1971) (dalam Daryanto, 2010); "Evaluation, as wee see it, is the systematic collection of evidence to determine whether in fact certain changes are taking place in the learners as well as to determine the amount or degree of change in individual students." Artinya: Evaluasi, sebagaimana kita lihat, adalah pengumpulan kenyataan secara sistematis untuk menetapkan apakah dalam kenyataannya terjadi perubahan dalam diri siswa dan menetapkan sejauh mana tingkat perubahan dalam pribadi siswa. Pada uraian lain Stufflebeam et. al; "Evaluation is the process of delineating, obtaining, and providing useful information for judging decision alternatives." Artinya: Evaluasi merupakan proses menggambarkan, memperoleh, dan menyajikan informasi yang berguna untuk menilai alternative keputusan. menyerap bahasa yang dihasilkan oleh orang lain.

Evaluasi merupakan bagian yang penting dalam pendidikan, hal ini mengingat dengan evaluasi akan mengetahui bagaimana proes pendidikan dilaksanakan, faktor-faktor apa yang menghambat maupun mendorong pencapaian tujuan pendidikan, bahkan dengan evaluasi dapat mengetahui tingkat keberhasilan suatu pendidikan. Evaluasi merupakan prosedur sistematis yang dilakukan sesuai dengan 
prosedur yang telah diatur dengan baik. Karena pelaksanaan evaluasi yang baik akan mendapatkan informasi yang akurat sesuai dengan tujuan yang diharapkan.

Evaluasi merupakan proses yang sistematis tentang pengumpulan, penganalisisan, penafsiran, dan pemberian keputusan tentang informasi yang dikumpulkan. Pengertian tersebut memiliki arti bahwa evaluasi bukanlah suatu hasil, melainkan suatu proses yang dilakukan secara sistematis. Proses yang terdapat dalam evaluasi merupakan proses yang berkelanjutan. Proses ini bukan diselenggarakan hanya pada akhir kegiatan melainkan deselenggarakan pada awal, pertengahan dan akhir kegiatan, artinya evaluasi dilakukan selama kegiatan berlangsung.

Adapun yang dimaksud dengan evaluasi perkembangan anak usia dini adalah suatu proses yang sistematik yang meliputi pengumpulan, penganalisisan, penafsiran dan pemberian keputusan tentang perkembangan anak usia dini. Evaluasi perkembangan anak usia dini dilaksanakan untuk mengetahui dan mendcceskripsikan perkembangan anak usia dini yang terjadi sebagai akibat adanya kegiatan yang diberikan.

Mengingat pentingnya evaluasi perkembangan anak usia dini, maka evaluasi perkembangan anak usia dini merupakan suatu keharusan dalam pengembangan anak usia dini. Karena evaluasi perkembangan anak usia dini yang kurang baik, dalam arti evaluasi perkembangan anak usia dini yang tidak dapat memberikan gambaran secara akurat tentang perkembangan anak usia dini, tentunya tidak dapat membantu usaha pengembangan yang dilakukan. Untuk dapat memperoleh gambaran secara aktual tentang perkembangan anak usia dini, maka evaluasi perkembangan anak usia dini harus dipahami dan dilakukan sebagai bagian yang tak terpisahkan dari proses pengembangan anak usia dini. Dengan demikian diharapkan evaluasi perkembangan anak usia dini dapat membantu anak usia dini untuk mengembangkan seluruh potensi yang dimilikinya.

\section{METODE}

Penelitian ini merupakan penelitian Research and Development $(R \& D)$ dengan menggunakan model pengembangan perangkat pembelajaran 4D Thiagarajan (Trianto, 2013), untuk mengembangkan perangkat evaluasi perkembangan bahasa anak usia dini pada anak TK Islam Al Markaz Al Islami kelompok B.
Pengembangan penelitian yang dikembangkan pada penelitian ini adalah perangkat evaluasi perkembangan bahasa anak usia dini. Penelitian Research and Development $(R \& D)$ adalah suatu proses yang dipakai untuk mengembangkan dan memvalidasi produk. Penelitian ini mengikuti langkah-langkah penelitian yang terdiri dari kajian penelitian produk yang dikembangkan (Buhari, 2011).

Instrumen pengumpulan data yang digunakan dalam penelitian ini adalah :

1. Observasi Kegiatan

2. Angket Respon Guru (ARG)

3. Dokumentasi

Adapun instrumen yang di validasi terdiri atas validasi instrumen produk dan validasi instrumen penelitian untuk pengembangan perangkat evaluasi perkembangan bahasa anak usia dini yang divalidasi oleh dua validator ahli di bidangnya yaitu:

1. Instrumen Validasi Produk terdiri atas: Buku Pedoman, Perangkat Evaluasi, dan RKA

2. Instrumen Validasi Untuk Mengukur Kemampuan Bahasa Anak terdiri atas: Lembar Evaluasi, dan LPKA.

\section{HASIL DAN PEMBAHASAN}

\subsection{Buku Pedoman Pengembangan Perangkat Evaluasi Perkembangan Bahasa Anak Usia Dini pada Taman Kanak-Kanak Kelompok B.}

Dapat dijelaskan bahwa nilai rata-rata total kevalidan Buku Pedoman Pengembangan Perangkat Evaluasi Perkembangan Bahasa Anak Usia Dini pada Anak Kelompok B diperoleh $\overline{\boldsymbol{x}}=$ 3,3 nilai ini termasuk dalam kategori Valid yaitu berada pada rentang $2,5 \leq \bar{X}<3,5$. Selain itu aspek isi buku dan bahasa dan penulisan memiliki kriteria kevalidan tinggi yaitu 3,5. Adapun perbaikan yang telah dilakukan pada Buku Pedoman Pengembangan Perangkat Evaluasi Perkembangan Bahasa Anak Usia Dini pada Anak Kelompok B sebagaimana disarankan oleh validator adalah sudah bisa digunakan dalam rangka proses penelitian.

\subsection{Perangkat Evaluasi Perkembangan Bahasa Anak Usia Dini pada Taman Kanak-Kanak Kelompok B.}


Berdasarkan hasil analisis dapat dijelaskan bahwa nilai rata-rata total kevalidan Perangkat Evaluasi Perkembangan Bahasa Anak Usia Dini pada Anak Kelompok B diperoleh $\overline{\boldsymbol{x}}=3,4$ berdasarkan criteria kevalidan nilai ini termasuk dalam kategori Valid yaitu berada pada rentang $2,5 \leq$ by $\bar{X}<3,5$. Selain itu aspek komponen perangkat dan manfaat/kegunaan perangkat memiliki kriteria kevalidan tinggi yaitu 3,5. Adapun perbaikan yang telah dilakukan sebagaimana disarankan oleh validator adalah sudah bisa digunakan dalam rangka proses penelitian.

\subsection{Lembar Pengamatan Aktivitas Guru (LPAG)}

Berdasarkan hasil analisis dapat dijelaskan bahwa nilai rata-rata total kevalidan Lembar Pengamatan Aktivitas Guru (LPAG) diperoleh $\overline{\boldsymbol{x}}$ $=3,33$ berdasarkan kriteria kevalidan nilai ini termasuk dalam kategori Valid yaitu berada pada rentang $2,5 \leq \bar{X}<3,5$. Selain itu aspek petunjuk dan aspek isi memiliki kriteria kevalidan tinggi yaitu 3,5. Adapun perbaikan yang telah dilakukan sebagaimana disarankan oleh validator adalah sudah bisa digunakan dalam rangka proses penelitian.

\subsection{Lembar Pengamatan Pengelolaan Pembelajaran (LPPP)}

Berdasarkan hasil analisis dapat dijelaskan bahwa nilai rata-rata total kevalidan Lembar Pengamatan Pengelolaan Pembelajaran (LPPP) diperoleh $\overline{\boldsymbol{x}}=3,4$ berdasarkan kriteria kevalidan nilai ini termasuk dalam kategori Valid yaitu berada pada rentang $2,5 \leq \bar{X}<3,5$. Selain itu aspek petunjuk, aspek isi, dan aspek penataan memiliki kriteria kevalidan tinggi yaitu 3,5. Adapun perbaikan yang telah dilakukan sebagaimana disarankan oleh validator adalah sudah bisa digunakan dalam rangka proses penelitian.

\subsection{Lembar Pengamatan Keaktifan Anak (LPKA)}

Berdasarkan hasil analisis dapat dijelaskan bahwa nilai rata-rata total kevalidan Lembar Pengamatan Keaktifan Anak (LPKA) diperoleh $\overline{\boldsymbol{x}}$ $=3,4$ berdasarkan kriteria kevalidan nilai ini termasuk dalam kategori Valid yaitu berada pada rentang $2,5 \leq \bar{X}<3,5$. Selain itu aspek bahasa memiliki kriteria kevalidan tinggi yaitu 3,5. Adapun perbaikan yang telah dilakukan sebagaimana disarankan oleh validator adalah sudah bisa digunakan dalam rangka proses penelitian.

\subsection{Angket Respon Guru (ARG)}

Berdasarkan hasil analisis dapat dijelaskan bahwa nilai rata-rata total kevalidan Angket Respon Guru (ARG) diperoleh $\overline{\boldsymbol{x}}=3,4$ berdasarkan kriteria kevalidan nilai ini termasuk dalam kategori Valid yaitu berada pada rentang $2,5 \leq \bar{X}<3,5$. Selain itu aspek petunjuk dan perangkat memiliki kriteria kevalidan tinggi yaitu 3,5. Adapun perbaikan yang telah dilakukan sebagaimana disarankan oleh validator adalah sudah bisa digunakan dalam rangka proses penelitian.

Deskripsi Hasil Penilaian Validator Terhadap Perangkat Pengembangan Perangkat Evaluasi Perkembangan Bahasa Usia Dini di Taman KanakKanak Kelompok B menunjukkan bahwa menurut penilaian validator terhadap perangkat pembelajaran yang meliputi Buku Pedoman Pengembangan Perangkat Evaluasi Perkembangan Bahasa Anak Usia Dini pada Taman Kanak-kanak Kelompok B, Perangkat Evaluasi (Lembar evaluasi), Lembar Pengamatan Aktivitas Guru (LPAG), Lembar Pengamatan Pengelolaan Pembelajaran (LPPP), Lembar Pengamatan Keaktifan Anak (LPKA), dan Angket Respon Guru (ARG) dinyatakan valid untuk digunakan.

\subsection{Gambaran Keterlaksanaan}

Gambaran keterlaksanaan evaluasi dilakukan dengan mengamati kemampuan guru dalam melakukan pengelolaan pembelajaran dan mengamati kegiatan guru dalam melakukan evaluasi. Ini dapat dilakukan melalui analisis kepraktisan dan gambaran keterlaksanaan.

\subsubsection{Analisis Kepraktisan}

Untuk mengukur tingkat kepraktisan perangkat evaluasi yang dikembangkan maka dilakukan pengamatan terhadap pengelolaan pembelajaran dengan menggunakan instrumen lembar observasi kemampuan guru dalam mengevaluasi kegiatan pembelajaran pada setiap aspek perkembangannya khususnya aspek perkembangan bahasa anak. Prosedur yang ditempuh adalah pengamat mengamati guru dalam 
mengevaluasi perkembangan bahasa anak dengan menggunakan perangkat pengembangan perangkat evaluasi perkembangan bahasa anak usia dini di Taman Kanak-Kanak Kelompok B ini dengan memberikan tanda " $"$ " pada kolom yang sesuai dengan skor penilaian yang diberikan. Pengamatan dilakukan setiap minggu selama penelitian berlangsung. Dari setiap hari pengamatan berlangsung dipilih satu hari dalam seminggu sebagai hari efektif untuk mengambil kesimpulan pengamatan guru dalam mengevaluasi anak usia dini di Taman Kanak-kanak Kelompok B.

Tujuan analisis data pengelolaan pembelajaran adalah untuk melihat tingkat kepraktisan Perangkat Evaluasi Perkembangan Bahasa Anak Usia Dini di Taman Kanak-Kanak Kelompok B. Agar lebih mudah menarik kesimpulan, maka data pengamatan dianalisis berdasarkan aspek bahasa anak.

Secara keseluruhan hasil pengamatan aktivitas guru pada lima kegiatan yakni 1) kegiatan memancing huruf, 2) kegiatan memasangkan gambar dengan kata, 3) kegiatan melengkapi kalimat, 4) kegiatan bercerita tentang gambar yang dibuat sendiri, dan 5) kegiatan mengelompokkan kata-kata sejenis dengan menggunakan perangkat evaluasi seperti tertera pada Lampiran B diperoleh nilai rata-rata 2,56 pada aktivitas guru. Berdasarkan kategori yang disebutkan pada Bab III nilai ini termasuk dalam kategori terlaksana dengan "baik" yaitu berada pada rentang $2,5 \leq \mathrm{TKG}<3,5$. Sedangkan pada pengelolaan pembelajaran diperoleh nilai ratarata 2,41. Berdasarkan kategori yang disebutkan pada Bab III nilai ini termasuk dalam kategori terlaksana dengan" cukup" yaitu berada pada rentang $1,5 \leq \mathrm{TKG}<2,5$. Namun demikian, masih ada beberapa hal yang masih perlu diperbaiki berdasarkan saran-saran dari pengamat, antara lain:

1) Guru masih perlu diberikan pemahaman tentang konsep evaluasi dan petunjuk agar lebih terampil dan memahami bagaimana melaksanakan evaluasi terhadap perkembangan bahasa anak dengan baik sesuai dengan kemampuannya.

2) Guru masih perlu untuk memahami penggunaan perangkat evaluasi perkembangan bahasa anak usia dini pada anak TK kelompok B (usia 5-6 tahun), agar program pengembangan perangkat evaluasi perkembangan bahasa anak dapat di terapkan atau diimplementaskan lebih optimal.
Hasil pengamatan pada uji coba tersebut di atas, tampak bahwa hampir semua aspek dalam komponen pengamatan guru mengelola pembelajaran dan guru menggunakan perangkat pembelajaran telah dapat terlaksana seluruhnya dengan baik.

\subsubsection{Gambaran Keterlaksanaan}

Tiga kriteria ketuntasan secara klasikal harus tercapai, kriteria tersebut adalah (a) ketercapaian tingkat perkembangan hasil belajar anak yaitu minimal $70 \%$ anak didik mencapai tingkat perkembangan hasil belajarnya berada pada kategori Terlihat $(\mathrm{T})$ terhadap perangkat evaluasi perkembangan bahasa anak usia dini pada anak taman kanakkanak kelompok B yang diarahkan bagi anak didik, (b) ) keaktifan anak didik selama kegiatan belajar memenuhi kriteria ideal apabila nilai KA minimal berada dalam kategori tinggi $(90 \% \leq \mathrm{KA})$, (c) pernyataan positif dari guru untuk setiap aspek yang direspon pada setiap komponen perangkat pembelajaran minimal memperoleh respon sebanyak $80 \%$ dari total respon tutor.

\subsubsection{Analisis Data Evaluasi Perkembangan Bahasa Anak Didik}

Perkembangan belajar anak didik pada aspek bahasa dari kegiatan yang telah diberikan kemudian dievaluasi dengan menggunakan perangkat evaluasi perkembangan bahasa anak usia dini. Evaluasi perkembangan bahasa anak didik dilakukan selama proses pembelajaran berlangsung, kemudian dicari persentase ratarata. Kemampuan anak didik dihitung berdasarkan kegiatan pada aspek bahasa yang diberikan dengan memunculkan 5 kegiatan yang tertera dalam buku pedoman sebagai tujuan pembelajaran.

Hasil yang diperoleh dari pengamatan perkembangan belajar anak didik sesuai aspek perkembangan bahasa dengan menggunakan perangkat evaluasi perembangan bahasa anak untuk kegiatan I sampai dengan kegiatan 5, dengan indikator bahasa yang dapat dicapai pada setiap kegiatan berada pada kategori Terlihat (T). Kegiatan 1 yaitu memancing huruf diperoleh $71 \%$ berada pada kategori terlihat (T), kegiatan 2 yaitu memasangkan gambar dengan kata diperoleh $78 \%$ berada pada kategori terlihat (T), kegiatan 3 yaitu melengkapi kalimat diperoleh $82 \%$ berada pada kategori terlihat (T), kegiatan 4 
yaitu bercerita tentang gambar yang dibuat sendiri diperoleh $74 \%$ berada pada kategori terlihat (T), kegiatan 5 yaitu mengelompokkan kata-kata sejenis diperoleh $76 \%$ berada pada kategori terlihat (T).

Dapat disimpulkan bahwa melalui lima kegiatan pengembangan perangkat evaluasi perkembangan bahasa anak usia dini yang diamati, rata-rata perkembangan belajar anak didik berada pada kategori terlihat (T) mendapat persentase $\geq 70 \%$, oleh guru memberikan keterangan dari lima kegiatan dalam pengembangan perangkat evaluasi perkembangan bahasa anak usia dini terlihat $(\mathrm{T})$ berada pada kategori $76,2 \%$.

\subsubsection{Analisis Data Angket Respon Guru (ARG)}

Penilaian oleh guru dilakukan untuk memperoleh masukan langsung dari guru terhadap perangkat evaluasi yang dibuat setelah divalidasi oleh para ahli. Kegiatan penilaian oleh guru dilakukan oleh peneliti sendiri dengan memberikan lembar angket kepada guru di TK Islam Al Markas Al Islami yang dianggap telah memiliki pengalaman mengajar. Hasil kegiatan tersebut kemudian dicatat untuk dijadikan sebagai bahan pertimbangan untuk merevisi perangkat evaluasi. Respon guru terhadap pengembangan perangkat evaluasi perkembangan bahasa anak usia dini pada anak TK kelompok B pada proses pelaksanaan pembelajaran sangat diperlukan. Jika dilihat dari kriteria diperoleh $95 \%$ respon guru yang positif pada setiap komponen perangkat evaluasi.

\subsubsection{Analisis Data Keaktifan Anak Didik (LPKA)}

Penilaian oleh guru dilakukan untuk memperoleh informasi tentang keaktifan anak dalam mengikuti kegiatan pembelajaran, sehingga dapat memudahkan guru dalam melakukan evaluasi khususnya pada aspek perkembangan bahasa anak. Hasil analisis keaktifan anak diperoleh persentase rata-rata keaktifan anak didik yakni 94,68 \% yang berarti berada dalam kategori tinggi.

Pada bagian ini dikemukakan pembahasan dari hasil penelitian yang meliputi tiga hal, yaitu: (1) ketercapaian tujuan penelitian, (2) hambatan dalam penelitian, dan (3) temuan khusus dalam penelitian. Pembahasan ketiga hal di atas dikemukakan sebagai berikut:

\subsection{Ketercapaian Tujuan Penelitian}

\section{a. Kevalidan}

Hasil pengamatan yang telah dilakukan di TK Islam Al Markaz Al Islami Makassar menunjukkan bahwa evaluasi yang dilakukan guru terhadap semua aspek perkembangan anak khususnya pada aspek perkembangan bahasa anak masih kurang maksimal. Evaluasi sangatlah penting untuk mendeskripsi ketercapaian pada semua aspek perkembangan anak, tidak terkecuali pada aspek perkembangan bahasa anak. Evaluasi terhadap perkembangan bahasa anak jarang bahkan terkadang tidak dilakukan oleh guru dan belum ada pengembangan khusus untuk perangkat evaluasi perkembangan bahasa anak yang bisa lebih memudahkan guru untuk memberikan penilaian terhadap perkembangan bahasa anak. Berdasarkan pengamatan langsung yang telah dilakukan di TK Islam Al Markaz Al Islami Makassar, menunjukkan bahwa dibutuhkan suatu buku pedoman yang dapat memudahkan guru dalam melakukan evaluasi terhadap perkembangan bahasa anak.

Berdasarkan hasil revisi dan penilaian oleh dua validator ahli yang dikemukakan sebelumnya dapat disimpulkan bahwa perangkat yang telah dikembangkan Buku Pedoman dengan nilai ratarata yaitu 3,3; Perangkat Evaluasi dengan nilai rata-rata yaitu 3,4; Lembar Pengamatan Aktifitas Guru (LPAG) dengan nilai rata-rata yaitu 3,33; Lembar Pengamatan Pengelolaan Pembelajaran (LPPP) dengan nilai rata-rata yaitu 3,4; Lembar Pengamatan Keaktifan Anak (LPKA) dengan nilai rata yaitu 3,4; dan Angket Respon Guru (ARG) dengan nilai rata-rata yaitu 3,4 dan secara keseluruhan telah memenuhi kriteria kevalidan. b. Segi Kepraktisan

Kepraktisan pengembangan perangkat evaluasi perkembangan bahasa anak usia dini, Dari desain pengembangan yang telah dilakukan berupa buku pedoman dan perangkat evaluasi perkembangan bahasa anak usia dini yang telah divalidasi dan secara keseluruhan hasil pengamatan kegiatan yang dilakukan oleh dua observer terhadap kegiatan guru dalam mengevaluasi kegiatan pembelajaran pada lima kegiatan bahasa yakni 1) kegiatan memancing huruf, 2) kegiatan memasangkan gambar dengan kata, 3) kegiatan melengkapi kalimat sederhana, 4) kegiatan bercerita tentang gambar yang dibuat 
sendiri, dan 5) kegiatan mengelompokkan katakata sejenis dapat dikatakan bahwa sudah memenuhi kriteria kepraktisan. Hal ini berdasarkan kategori yang disebutkan pada Bab III nilai ini termasuk dalam kategori baik yaitu berada pada rentang $2,5 \leq \mathrm{TKG}<3,5$.

c. Segi Keterlaksanaan Metode

Telah dikemukakan pada bab III kriteria keterlasanaan perangkat pembelajaran yang meliputi (1) ketercapaian tingkat perkembangan hasil belajar anak yang diperoleh dari evaluasi perkembangan belajar anak didik (LPPBAD) yaitu minimal $70 \%$ anak didik mencapai tingkat perkembangan hasil belajarnya terihat $(\mathrm{T})$ terhadap aspek pembelajaran bahasa untuk mengembangkan perangkat evaluasi perkembangan bahasa anak usia dini pada anak TK kelompok B, (2) keaktifan anak didik selama kegiatan belajar memenuhi kriteria ideal apabila nilai KA minimal berada dalam kategori tinggi $(90 \% \leq \mathrm{KA})$, (3) pernyataan positif dari guru untuk setiap aspek yang direspon pada setiap komponen perangkat/instrumen evaluasi minimal memperoleh respon sebanyak $80 \%$ dari total respon guru, Pengembangan Perangkat Evaluasi Perkembangan Bahasa Anak Usia Dini pada Anak Taman Kanak-kanak Kelompok B yang diterapkan minimal berada dalam kategori terlihat (T), dengan syarat kriteria harus dipenuhi.

Dari ketiga indikator di atas, pada saat penelitian berlangsung terdapat 3 aspek yang telah terpenuhi yakni aspek (1) perkembangan belajar anak didik memenuhi $70 \%$ kriteria terlihat (T) yakni $76,2 \%$, (2) persentase rata-rata keaktifan anak didik yakni 94,68\% yang berarti berada dalam kategori tinggi dan (3) hasil analisis angket respon guru atau pernyataan positif dari guru untuk setiap aspek yang direspon pada setiap komponen perangkat evaluasi diperoleh persentase 95\%. Hal ini berarti Pengembangan Perangkat Evaluasi Perkembangan Bahasa Anak Usia Dini Pada Anak Taman Kanak-kanak Kelompok B yang telah diterapkan memiliki kriteria keterlaksanaan untuk diterapkan dalam proses pembelajaran.

\subsection{Hambatan dalam Penelitian}

Penelitian yang dilakukan dilapangan tidaklah semulus yang peneliti harapkan, ada beberapa hambatan yang peneliti temui. Hambatan dalam penelitian yang dikemukakan, yaitu hambatan selama proses pengembangan perangkat evaluasi, menyangkut tentang pengembangan perangkat di kelas. Adapun hambatan-hambatan yang dimaksud, yaitu:

a) Pemahaman guru terhadap perangkat evaluasi perkembangan bahasa anak usia dini yang dikembangkan masih belum maksimal. Hal tersebut dikarenakan kesibukan guru untuk membaca buku pedoman pelaksanaan evaluasi yang kurang, sehingga perlu untuk diberikan arahan-arahan kepada guru selama pelaksanaan agar tercapai tujuan evaluasi sebagaimana yang diharapkan.

b) Pelaksanaan evaluasi terhadap perkembangan bahasa anak yang disesuaikan dengan skenario pembelajaran tidak dilakukan secara maksimal, hal tersebut dikarenakan guru masih perlu pemahaman mengenai evaluasi itu sendiri.

\section{10 Temuan Khusus}

a) Kurangnya rasa percaya diri yang dimiliki oleh anak sehingga pada saat kegiatan pembelajaran berlangsung anak tidak memiliki keberanian untuk menunjukkan kemampuan yang dimilikinya, misalnya ketika guru bertanya anak hanya diam dan sesekali mengangguk, hal tersebut menyulitkan guru dalam memberikan nilai pada saat melakukan evaluasi terhadap perkembangan bahasa anak.

b) Evaluasi perkembangan bahasa anak yang didukung dengan buku pedoman dalam mengevaluasi, dapat memberikan kemudahan kepada guru dalam melakukan evaluasi terhadap perkembangan bahasa anak usia dini.

\section{KESIMPULAN}

Berdasarkan hasil penelitian dan pengembangan ini, maka dapat ditarik kesimpulan sebagai berikut:

a. Gambaran pelaksanaan evaluasi dalam rangka mengetahui perkembangan bahasa anak yang diterapkan di lapangan tidak sesuai dengan harapan, guru terkadang tidak melakukan evaluasi khususnya pada perkembangan bahasa anak dan anak kurang terlibat aktif dalam pembelajaran. Berdasarkan permasalahan yang ada, maka dianggap perlu untuk merancang sebuah perangkat evaluasi perkembangan bahasa anak usia dini.

b. Hasil dari gambaran desain pengembangan perangkat evaluasi perkembangan bahasa anak usia dini yang dikembangkan dalam 
penelitian ini ditinjau dari keseluruhan aspek dinyatakan valid. Desain pengembangan perangkat evaluasi perkembangan bahasa anak usia dini yang disusun peneliti dapat diterapkan, yakni; buku pedoman dan perangkat evaluasi.

c. Perangkat evaluasi perkembangan bahasa anak usia dini digunakan untuk mengetahui tingkat perkembangan bahasa anak. Perangkat evaluasi perkembangan bahasa anak usia dini dapat diterima dengan baik oleh guru, karena dengan adanya perangkat evaluasi tersebut dapat memberikan kemudahan kepada guru dalam mengevaluasi perkembangan bahasa anak.

\section{DAFTAR RUJUKAN}

Abdurrahman Mulyono. 2012. Anak Berkesulitan Belajar: Teori, Diagnosis, dan Remediasinya. Jakarta: Rineka Cipta.

Arifin Zainal. 2013. Evaluasi Pembelajaran: Prinsip, Teknik, Prosedur. Bandung: PT Remaja Rosdakarya Offset.

Arikunto Suharsimi dan Safruddin Cepi. 2009. Evaluasi Program pendidikan: Pedoman Teoretis Praktis bagi Mahasiswa dan praktisi Pendidikan. Jakarta: PT Bumi Aksara.

Ayu Widya dan Susilawati. 2013. Pengembangan Penilaian dalam Pendidikan Anak Usia Dini. Jakarta: Kementerian Pendidikan dan Kebudayaan.

Beaty J. Janice. 2013. Observasi Perkembangan Anak Usia Dini. Jakarta: Kencana Prenadamedia Group.

Buhari, 2011. Model-model Pengembangan Perangkat Pembelajaran. Tersedia. http:bustangbuhari.wordpress.com/2011/0 8/25/four-d-model-model-pengembanganperangkat-pembelajaran-dari-thiagarajan$\mathrm{dkk}$. Online. Diakses tanggal 19 September 2014

Busthomi Yasid, M. 2012. Panduan Lengkap PAUD: Melejitkan Potensi dan Kecerdasan Anak Usia Dini. Jakarta: Citra Publishing.

Catron E Carol dan Allen Jan. 1999. Early Childhood Curriculum: A Creative-Play Model. By Prentice-Hall, Inc.

Daryanto, H. 2010. Evaluasi Pendidikan. Jakarta: Rineka Cipta.
Departemen Pendidikan Nasional. 2003. Undang-undang Republik Indonesia Nomor 20 Tahun 2003 tentang Sistem Pendidikan Nasional. Jakarta

Dhieni, N., Fridani, L., Yarmi, G., Kusniaty, N. 2012. Metode Pengembangan Bahasa. Universitas Terbuka, Departemen Pendidikan Nasional.

Fridani Lara, Wulan Sri, Pujiastuti Indah Sri. 2010. Evaluasi Perkembangan Anak usia Dini. Jakarta: Universitas Terbuka.

Http://Edukasi.Kompasiana.Com/2014/04/16/Ba gaimanakah-Perkembangan-Bahasa-PadaAnak-Usia-Dini-Aud-647187.Html.

Diakses pada hari selasa, tanggal 10 Maret 2015 pukul 19.25.

Nieeven, N. 1999. Prototype to reach product quality. Dlm. Van Den Akker, J., Branch, R.M., Gustafson, K., Nieveen, N., \& Plomp, T. Design and tools in ducational and training. Dordrecht: Kluwer Academic Publisher.

Nurdin. 2007. Model Pembelajaran Matematik yang Menumbuhkan Kemampuan Metakognitif untuk Menguasai Bahan Ajar. Disertasi tidak diterbitkan. Surabaya: PPs UNESA.

Permendiknas nomor 58 tahun 2009 tentang Standar PAUD.

Salam, Sofyan.,Deri Bangkona 2010. Pedoman Penulisan Tesis dan Disertasi. Makassar: Badan Penerbit Universitas Negeri Makassar.

Sefrina Andin. 2013. Deteksi Minat Bakat Anak. Yogyakarta: Media Pressindo

Siantayani, Yulianti. 2011. Persiapan Membaca Bagi Balita. Yogyakarta: Krizter Publisher.

Sugiyono. 2013. Metode Penelitian Pendidikan: Pendekatan Kualitatif, kuantitatif, dan R \& D. Bandung: Alfabeta.

Susanto Ahmad. 2011. Perkembangan Anak Usia Dini: Pengantar dalam Berbagai Aspeknya. Jakarta: Kencana Prenada Media Group.

Suyanto. S. 2005. Dasar-Dasar Pendidikan Anak Usia Dini. Yogyakarta: Hikayat.

Thoha Chabib.2003. Teknik Evaluasi Pendidikan. Jakarta: PT RajaGrafindo Persada.

Trianto. 2011. Pengantar Penelitian Pendidikan bagi Pengembangan Profesi Pendidikan dan Tenaga Kependidikan. Jakarta: Kencana Prenada Media Group. 
Uno B. Hamzah dan Koni Satria. 2012. Assessment Pembelajaran. Jakarta: PT Bumi Aksara.

UU No. 20 Tahun 2003 tentang Sistem Pendidikan Nasional

Yus Anita. 2005. Penilaian Perkembangan Belajar Anak Taman Kanak-Kanak. Jakarta: Departemen Pendidikan Nasional Direktorat Jenderal Pendidikan Tinggi.

Yus Anita. 2011. Penilaian Perkembangan Belajar Anak Taman Kanak-Kanak. Jakarta: Kencana Prenada Media Group.

Wasesa, I. (2005). Evaluasi pembelajaran TK. Jakarta: Pernerbit UT. 